\title{
Diagnostics and Management of Male Infertility in Primary Ciliary Dyskinesia
}

\author{
Channa N. Jayasena ${ }^{1}\left[\right.$ and Anu Sironen ${ }^{2, *}$ \\ 1 Section of Investigative Medicine, Imperial College London, London W12 0NN, UK; \\ c.jayasena@imperial.ac.uk \\ 2 Natural Resources Institute Finland, Production Systems, 31600 Jokioinen, Finland \\ * Correspondence: anu.sironen@luke.fi; Tel.: +358-401862411
}

Citation: Jayasena, C.N.; Sironen, A. Diagnostics and Management of Male Infertility in Primary Ciliary

Dyskinesia. Diagnostics 2021, 11, 1550. https://doi.org/10.3390/

diagnostics 11091550

Academic Editor: Thomas Burgoyne

Received: 14 June 2021

Accepted: 19 August 2021

Published: 26 August 2021

Publisher's Note: MDPI stays neutral with regard to jurisdictional claims in published maps and institutional affiliations.

\begin{abstract}
Primary ciliary dyskinesia (PCD), a disease caused by the malfunction of motile cilia, manifests mainly with chronic recurrent respiratory infections. In men, PCD is also often associated with infertility due to immotile sperm. Since causative mutations for PCD were identified in over 50 genes, the role of these genes in sperm development should be investigated in order to understand the effect of PCD mutations on male fertility. Previous studies showed that different dynein arm heavy chains are present in respiratory cilia and sperm flagellum, which may partially explain the variable effects of mutations on airways and fertility. Furthermore, recent studies showed that male reproductive tract motile cilia may play an important part in sperm maturation and transport. In some PCD patients, extremely low sperm counts were reported, which may be due to motile cilia dysfunction in the reproductive tract rather than problems with sperm development. However, the exact roles of PCD genes in male fertility require additional studies, as do the treatment options. In this review, we discuss the diagnostic and treatment options for men with PCD based on the current knowledge.
\end{abstract}

Keywords: PCD; sperm; male fertility; ICSI

\section{Introduction}

Primary ciliary dyskinesia (PCD) is caused by mutations in the genes required for motile axoneme formation and function. The axoneme is a microtubular structure consisting of nine outer doublets and two central microtubules (Figure 1).

In motile cilia, the motor force for movement is generated by outer and inner dynein arms (ODA and IDA, respectively), which are coordinated by the nexin-dynein regulatory complex (N-DRC), radial spokes (RS), and the central pair (CP) microtubules. The N-DRC complex also forms connections with other axonemal complexes within the ciliary unit and, thus, likely plays a role of a main regulatory hub [2]. These structures are also present in the sperm tail axoneme and are required for sperm motility and, therefore, for male fertility. Recent studies have identified protein components of different axonemal structures and preassembly factors [3-5], which can be considered as candidate genes for PCD and male infertility. However, the structure of motile cilia and sperm tails are not identical. The most obvious difference is the sperm tail length, which is $5-10$ times longer than a cilium. A sperm tail contains accessory structures in addition to the core axoneme (Figure 1) and can be divided into three parts: the midpiece, principal piece, and end piece. Outer dense fibers (ODFs) run along the midpiece and principal piece, supporting the long axoneme. The principal piece contains the fibrous sheath and the midpiece contains mitochondria, which produce energy for sperm motility [6]. The sperm tail axoneme is often disintegrated when ODFs and the fibrous sheath are malformed [7-9]. The midpiece and principal piece are separated by a diffusion barrier called the annulus (Figure 1). The sperm tail is connected to the head through the head-tail coupling apparatus (HTCA), which is formed by the modification of the centrosomes and the formation of supporting structures to connect the tail to the implantation fossa of the nuclear membrane [10,11]. Furthermore, 
the axonemal protein complexes may differ in protein content between motile cilia types, which was recently demonstrated by the identification of sperm tail specific dynein heavy chains $[12,13]$. The different motility patterns of sperm tails and motile cilia likely originate in part from the variable composition of axonemal structures [14,15]. More research is required to establish the specific characteristics of the sperm axoneme.

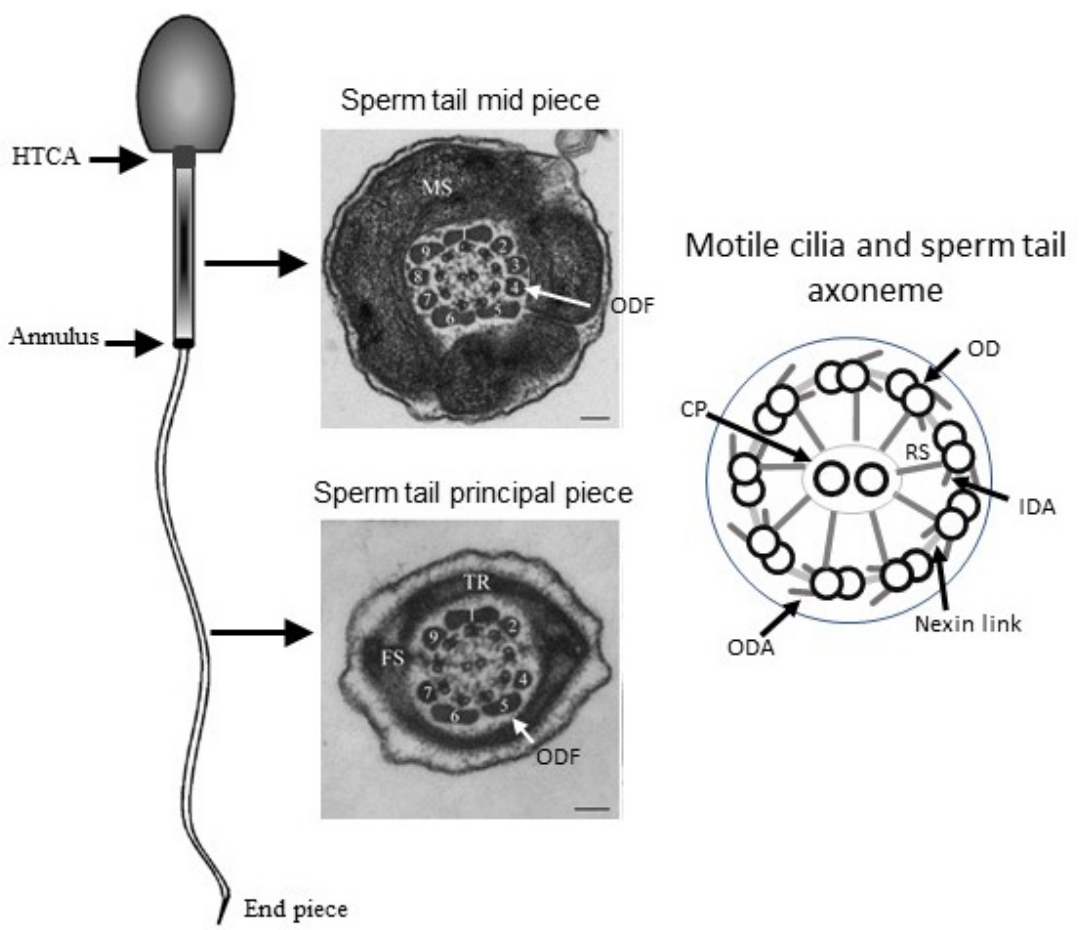

Figure 1. The conserved axonemal core structure is present in motile cilia and sperm flagella. The sperm tail can be divided into three parts: the midpiece, principal piece, and end piece. Outer dense fibers (ODFs) run along the mid and principal piece, and mitochondria (MS, mitochondrial sheath) surround the ODFs in the midpiece. In the principal piece, ODFs 3 and 8 are replaced by transfers ribs (TR) and form part of the fibrous sheath (FS). The annulus is a diffusion barrier between the midpiece and principal piece, and the sperm tail is connected to the head by the head-tail coupling apparatus (HTCA). The axoneme runs along the whole tail and appears ultrastructurally identical in the sperm flagellum and motile cilia, containing nine outer doublet microtubules (OD) and a central pair (CP). Radial spokes (RD) connect the ODs to the CP and nexin links connect the adjacent ODs. The head-tail coupling apparatus (HTCA) connects the sperm tail to the head and is formed by the centriole attachment to the nucleus. The annulus is a diffusion barrier between the midpiece and principal piece. The sperm illustration and TEM images are reproduced with the Creative Commons CC by license [1].

\section{Role of PCD Genes in Male Fertility}

Male infertility is often associated with PCD, but the pathogenic mechanisms linking PCD mutations to defective sperm function are less well understood. Thus far, mutations in approximately 50 genes have been identified as the cause of PCD, and the number of genes has rapidly increased during recent years $[16,17]$. Most of the PCD genes are expressed in the testis, although extremely low expression is detected for the multiciliogenesis gene MCIDAS, the ODA genes DNAH5 and DNAH11, and the RS gene RSPH4A (Figure 2). 


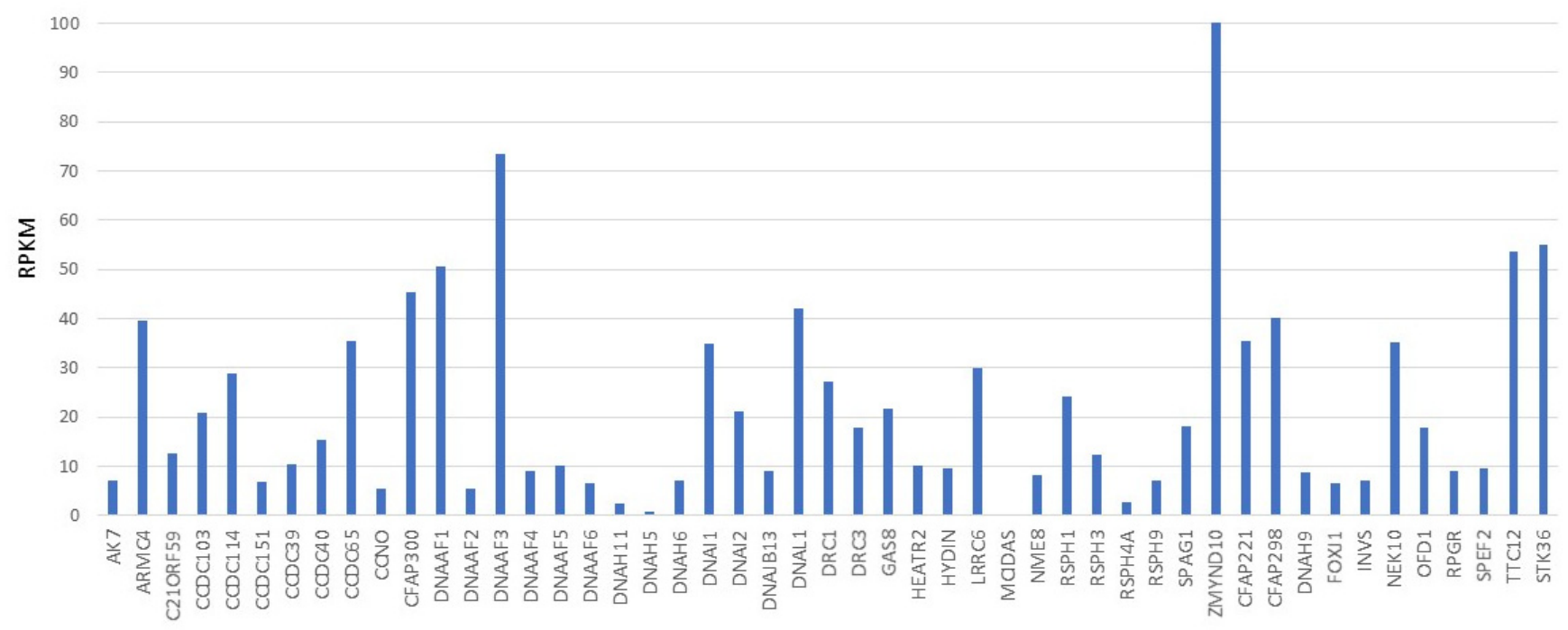

Figure 2. PCD gene expression in the human testis. Variable expression of known PCD genes are detected in NGS data by Fagerberg et al. [18]. RPKM reads per kilobase of transcript per million reads mapped.

PCD genes can be divided into different categories: multiciliogenesis, dynein arm preassembly, ODA/IDA, RS/CP, and genes associated with nexin links and microtubular organization. Current knowledge on the roles of these genes in motile cilia and sperm development was recently reviewed by Shoemark and Harman [19] and Sironen et al. [20], respectively. The effects of RS/CP gene mutations on male fertility are poorly known. CP components HYDIN [1] and SPEF2 [21] cause male infertility and PCD. In addition, mutations in SPEF2 result in a sperm-specific defect: multiple morphological abnormalities of the sperm flagella (MMAF) [22,23]. Other CP components associated with MMAF are AK7, ARMC2, and CFAP69 [24-27]. For AK7 (adenylate kinase 7), an association with PCD has also been suggested [28,29]. Male infertility was likewise reported for mutations in the RS genes RSPH1, RSPH3, and RSPH9 [30-32], but, as suggested by low expression in the testis (Figure 2), RSPH4A does not seem to be required for fertile sperm production. This assumption is also supported by the fact that all reported PCD patients are fertile [31], although reported patient numbers are very low for all RS genes (number of patients 1-3). A candidate compensating gene for RSPH4A in the testis is RSPH6A, which is predominantly expressed in the testis [33]. Previous studies and expression data suggest that dynein arm preassembly genes are required for sperm motility and, therefore, mutations in these genes can be expected to cause male infertility (Figure 2, [34]), although differences in assembly mechanisms exist. A lack of dynein arm preassembly factor TTC12 results in IDA and ODA loss in sperm flagellum, but only partial loss of IDA in motile cilia [35]. This further supports the hypothesis of different dynein arm complexes in sperm and motile cilia, which has been suggested by reported variable fertility in PCD patients with mutations in genes coding for ODA [20,31,36,37].

\subsection{Sperm Specific Dynein Heavy Chain Genes}

Although the ultrastructures of motile cilia and sperm tail axoneme are similar, there are differences in the protein content of the dynein arm components. Recent studies and expression analysis (Figure 2) have shown that motile cilia dynein heavy chains DNAH5 and DNAH11 are not present in sperm, which suggests that mutations in these genes do not cause male infertility $[12,13,20]$. However, cases of infertility have been reported for patients with mutations in DNAH5 and DNAH11 [31,36,37]. Furthermore, mutations in DNAH1, $D N A H 2, D N A H 8$, and DNAH17 have been shown to cause predominant male infertility, although mild PCD symptoms may be present [13,38-49]. Interestingly, asthenospermia without PCD symptoms was recently reported in two patients with DNAH9 mutations [50]. DNAH9 is a known PCD gene, which is required for distal ODA assembly in motile cilia and 
causes mild PCD symptoms [51,52]. The expression pattern of axonemal genes suggests cell specific differences in protein complexes, which may explain the unique motility patterns of motile cilia and sperm tails (Figure 2, [20]). However, these differences require additional research to confirm the role of DNAH genes in male fertility.

\subsection{Male Specific Motile Cilia}

Male germ cells differentiate in the seminiferous tubules of the testes and are released into the lumen of these tubules for transport to the epididymis. During this transit, sperm are concentrated and matured before being stored in the cauda epididymis for subsequent ejaculation. When sperm exit the testis, they first enter a series of thin ciliated tubules, the efferent ductules (ED, Figure 3), which connect the rete testis to the epididymis.

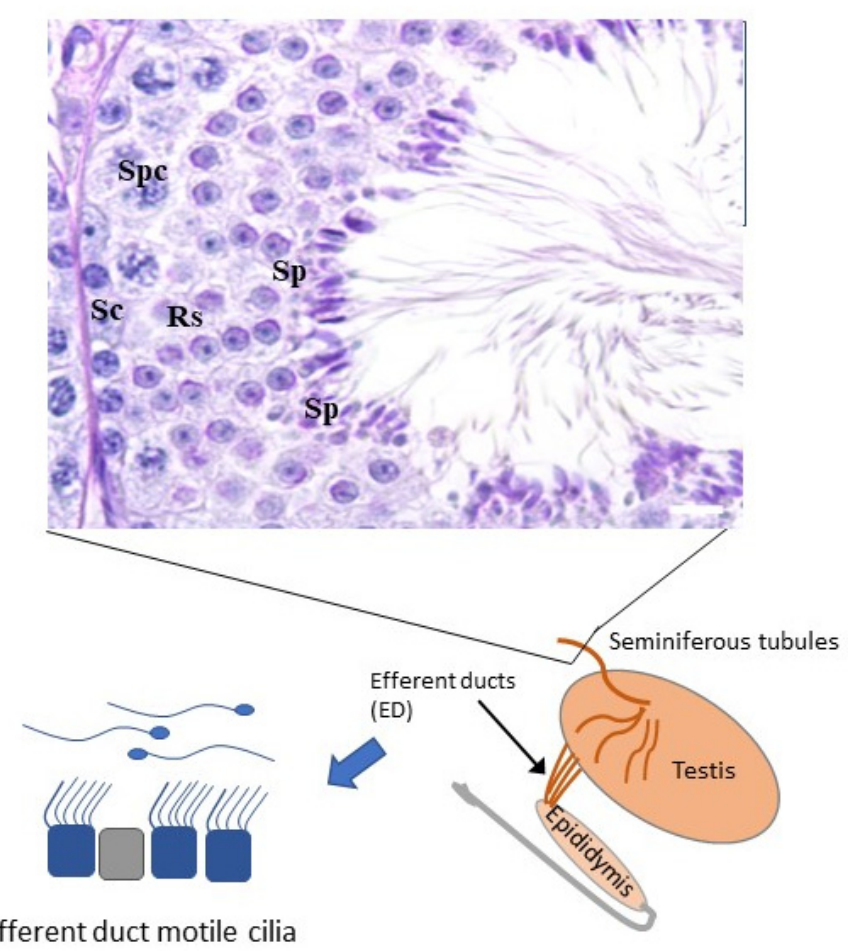

Figure 3. Sperm development and maturation. Male germ cells develop in seminiferous tubules of the testis. After release into the lumen of the seminiferous tubules, sperm are transported through the efferent ductules and epididymis and stored in the cauda epididymis. Efferent ductules contain motile cilia, which were shown to be crucial for male fertility in mouse models [53]. Spc = spermatocyte, $\mathrm{Rs}=$ round spermatid, $\mathrm{Sc}=$ Sertoli cell, $\mathrm{Sp}=$ spermatid.

The ED ciliated epithelial cells are thought to create a fluid turbulence that concentrates sperm by promoting fluid absorption by neighboring non-ciliated cells [53,54]. Multiciliogenesis regulator knock-out $(\mathrm{KO})$ mouse models have shown that $\mathrm{ED}$ cilia are required for male fertility [53] since MCIDAS, CCNO and GEMC1 are not expressed in the testis (cells are not multiciliated, Figure 2), but are in ED. Depletion of these genes in KO mice resulted in lack of sperm in the epididymis (azoospermia) [53]. Fluid accumulation in multiciliogenesis KOs caused back pressure to the seminiferous tubules and degeneration of spermatogenesis [53]. The identified azoospermia phenotype in mice may be partially caused by defects in sperm transport and degeneration of spermatogenesis. These results suggest that genes may affect male fertility in PCD patients, although they are not required for sperm development. The roles of ED cilia in PCD patients are not known, but, in addition to sperm tail formation, it should be considered that the malfunction of ED cilia may contribute to male infertility. 


\section{Diagnosing Male Infertility in PCD Patients}

\subsection{Semen Quality Analysis}

The overall prognosis of fertility in men with PCD has not been defined clearly; however, a previous study indicated that $75 \%$ of couples affected by PCD in the male partner were diagnosed as infertile [31]. Since there is a high chance of infertility in PCD patients, this information should be included in patient counselling, particularly during transition from pediatric care to adult clinics. Since there is not enough information about the roles of different PCD genes in sperm production and maturation, sperm quality should be analyzed prior to family planning. Semen analysis in fertility clinics, based on WHO guidelines (WHO, 2010), provides the initial assessment of fertility. The analysis will estimate the sperm concentration, motility, and morphology, which are used to classify the sperm phenotype (Table 1). In PCD patients, low sperm counts, decreased motility, and/or morphological abnormalities can be expected [20].

Table 1. Classification of sperm phenotypes.

\begin{tabular}{cc}
\hline Defect & Sperm Phenotype \\
\hline Normozoospermia & Normal ejaculate and semen parameters \\
Azoospermia & No sperm in the ejaculate \\
Oligozoospermia & Sperm concentration $<15$ million $/ \mathrm{mL}$ \\
Asthenozoospermia & Sperm motility $<40 \%$ \\
Teratozoospermia & Normal morphology $<4 \%$ \\
Oligoasthenozoospermia & Sperm concentration $<15 \mathrm{million} / \mathrm{mL}$ \\
Oligoteratozoospermia & Sperm motility $<40 \%$ \\
& Sperm concentration $<15 \mathrm{million} / \mathrm{mL}$ \\
Asthenoteratozoospermia & Normal morphology $<4 \%$ \\
& Sperm motility $<40 \%$ \\
Oligoasthenoteratozoospermia & Normal morphology $<4 \%$ \\
& Sperm concentration $<15 \mathrm{million} / \mathrm{mL}$ \\
& Sperm motility $<40 \%$ \\
& Normal morphology $<4 \%$ \\
\hline
\end{tabular}

For sperm quality estimation, a sperm sample is produced after $72 \mathrm{~h}$ of ejaculation avoidance. At the fertility clinic, medical history and information about any factors influencing fertility will be collected. Testicular size and hormonal levels are evaluated in addition to sperm quality. Sperm quality estimates include sperm count, volume, head and tail morphology, total and progressive motility, and $\mathrm{pH}$. The correct $\mathrm{pH}$, which is 7.2-7.8 according to the WHO, is important for sperm motility and capacitation [55]. Decreased fertility can be expected if values are below normal (Table 2).

Table 2. Normal sperm quality parameters based on WHO guidelines.

\begin{tabular}{cc}
\hline & WHO Reference Range \\
\hline Total sperm count in ejaculate & $39-928$ million \\
Ejaculate volume & $1.5-7.6 \mathrm{~mL}$ \\
Sperm concentration & $15-259$ million per mL \\
Total motility (progressive and & $40-81$ percent \\
non-progressive) & $32-75$ percent \\
Progressive motility & $4-48$ percent \\
Sperm morphology &
\end{tabular}

In the case of reduced fertility, assisted reproductive technology (ART) can be considered based on sperm quality analysis. Although semen microscopic analysis is the first stage of diagnosis, molecular testing is needed to more precisely evaluate the sperm quality, especially prior to ART. 


\subsection{Sperm Viability}

Semen analysis provides a general view of the sperm quality, but in the case of immotile sperm in PCD patients, it is also important to assess the sperm viability prior to the use of ART. Fertilization rates using immotile sperm are significantly lower than with motile sperm, underlining the importance of identification of good-quality sperm [56]. Use of immotile or malformed sperm for fertilization may increase the likelihood of selecting nonviable sperm as has also been suggested by sperm viability and fertilization studies in PCD patients $[57,58]$. The human sperm viability can be analyzed using various methods: chemical sperm activation, light microscopy including eosin staining, hypoosmotic swelling test (HOST), Sybr-14/propidium iodide assay, sperm tail flexibility test (STFT), and laser-assisted immotile sperm selection (LAISS). The methods assess the plasma membrane integrity, which also plays an important role in sperm capacitation, acrosome reaction, hypermotility, and sperm fusion with the oocyte.

HOST: sperm is placed in a hypo-osmotic medium, where viable sperm tails curve or swell. These spermatozoa can be selected for fertilization and washed to regain their normal shape. HOST was shown to increase fertilization rates from $30 \%$ to $44 \%$ in fresh testicular sperm and from $26 \%$ to $43 \%$ in frozen testicular sperm [59]. The method has also been successfully employed in PCD patients, with several successful pregnancies resulting $[57,60-62]$. The limitations with HOST are the high false positive rate and that it is not suitable for cryopreserved and processed ejaculated sperm.

Sperm activation: chemical sperm activation can be induced by pentoxifylline or theophylline and responsive sperm selected for use in ART. The pentoxifylline treatment was shown to be significantly more effective than HOST for identification of spermatozoa in terms of fertilization (62\% vs. $41 \%$ ) and clinical pregnancy rates (32\% vs. $16 \%$ [63]). PCD sperm is often unresponsive to chemical activation, but pentoxifylline was successfully used to activate ejaculated spermatozoa prior to fertilization, resulting in viable pregnancy [64]. However, the use of sperm activation is limited in PCD sperm and the safety of the chemical compounds should be considered.

STFT: the sperm tail flexibility test is based on a simple principal that the viable sperm tail can be bent by a mechanical force. STFT can be very reliable and similar fertilization rates with testicular immotile or motile sperm ( $66 \%$ vs. $74 \%$ frozen and $73 \%$ vs. $64 \%$ fresh, respectively), and comparable pregnancy and healthy baby rates were reported [65]. STFT is safe for the developing embryo, as there are no additives, and it is simple and quick to perform, although it requires highly experienced personnel. This method has been successfully used in PCD patients [66].

LAISS: in laser-assisted immotile sperm selection, a single laser shot is directed to the tip of the flagellum, which causes curling or coiling of the tail in viable sperm. Identification of viable testicular spermatozoa was shown to be comparable to that of the HOS test, and LAISS was also successfully used for selection of cryopreserved immotile sperm [67]. The fertilization rate increased significantly from $20 \%$ in the randomly selected testicular sperm group, to $45 \%$ in the laser selection group; accordingly, the take home baby rate increased from $6 \%$ to $19 \%$. The method is quick, easy, repeatable, and safe, but it requires expensive instruments and experienced personnel [60]. LAISS has also been used successfully in PCD patients $[68,69]$. One study resulted in a healthy baby by LAISS-selected sperm after three unsuccessful treatment cycles, indicating the usefulness of the method in treating male infertility in PCD [69].

Based on the current knowledge, LAISS appears to be the most simple, safe, and reliable method of choice for viable sperm selection. The HOS test and sperm activation require the use of added chemicals, which may influence the embryo development. HOST and STFT are limited in selecting frozen, thawed spermatozoa, while STFT requires highly experienced personnel. When LAISS was compared to the tail flexibility test, superior reliability was concluded [60].

A high sperm DNA fragmentation rate is also strongly associated with low viability [70] and correlates with poor semen parameters (reduced count, motility, and mor- 
phology) [71,72]. In oligoasthenospermic men, it was found that $35-70 \%$ of immotile spermatozoa had poor DNA integrity in their nuclei [73]. More than $30 \%$ fragmentation rate indicates difficulty in achieving a healthy pregnancy and a higher likelihood of failed fertility treatment and miscarriage once pregnancy is achieved. Studies of DNA fragmentation in a case of repeated failed intra-cytoplasmic sperm injection (ICSI) cycles in PCD patients showed a high DNA damage rate ( $85 \%)$ as a possible cause of the ICSI failure [74]. The high presence of somatic cells in the ejaculate producing reactive oxygen species, may have also contributed to single-strand DNA breaks in sperm [74]. Thus, analysis of DNA fragmentation levels in PCD patients should be considered prior to ICSI to avoid unsuccessful treatment cycles and to allow for treatment accordingly with, for example, antioxidant treatment. The sperm chromatin structure assay, used to detect the DNA fragmentation index (DFI), is a routine test to estimate sperm DNA damage. Recently, a simultaneous detection of sperm membrane integrity and DNA fragmentation assay was tested using flow cytometry and co-staining, consisting of acridine orange $(\mathrm{AO})$ and LIVE/DEAD ${ }^{\mathrm{TM}}$ fixable blue dead cell stain [75], to estimate sperm quality prior to selection for ART. In the case of high DNA fragmentation, testicular sperm can be selected for ICSI.

\section{Treating Male Infertility in PCD}

Diagnostic semen analysis gives insights to the likely chance of a couple conceiving naturally or by ART. In the case of subfertility or the minor decrease in normal sperm parameters, the environmental factors should also be considered in counselling patients. Observational studies have suggested that smoking, drug use, obesity, alcohol, stress, and medication are associated with poor sperm quality in men [76]. Thus, the risk factors for poor sperm quality should be eliminated prior to any other treatment considerations.

In PCD, sperm motility is often dramatically decreased and therefore ART is often required for fertilization. In vitro fertilization (IVF) or ICSI can be offered to the couple when sperm count or motility is low, but viable sperm is present in the ejaculate. ICSI is the method of choice for immotile sperm. However, poor quality samples have a reduced success rate in ICSI and therefore sperm should be carefully selected [77,78]. An increased number of sperm with poor morphology does not seem to reduce IVF or ICSI success [79], but when only abnormal sperm are present, ICSI success is decreased [80]. Normally, sperm motility is a good predictive estimate for IVF/ICSI success [78]; unfortunately, many PCD patients have totally immotile sperm. Therefore, evaluation of sperm viability is crucial for sperm selection in PCD patients. This is also important for selection against sperm DNA fragmentation and chromosomal errors, since poor quality sperm can lead to low pregnancy rates and aneuploid embryos [81].

In the case of azoospermia (a complete lack of sperm in the ejaculate), testicular sperm can be retrieved for the female partner to be used during ICSI. In men with PCD, azoospermia is rare [82-84], but low sperm counts (oligospermia) are often reported [57,69,74,85,86]. Sperm can be retrieved by testicular sperm aspiration (TESA), which involves aspiration of testicular tissue using needles or by surgical procedures, conventional testicular sperm extraction (cTESE), and microdissection testicular sperm extraction (mTESE). In mTESE, light microscopy is used to identify engorged seminiferous tubules, which are then dissected and inspected intraoperatively for any sperm [87]. This method is superior for the identification of viable sperm when compared to TESA and cTESE. Successful sperm retrieval has been reported in $17-45 \%$ of cTESE cases and in $45-63 \%$ of mTESE cases [88,89]. The use of testicular sperm can also be an option when the sperm viability is low in ejaculated sperm.

The treatment pathway should be decided for each patient based on the outcome of the semen analysis (Figure 4). 


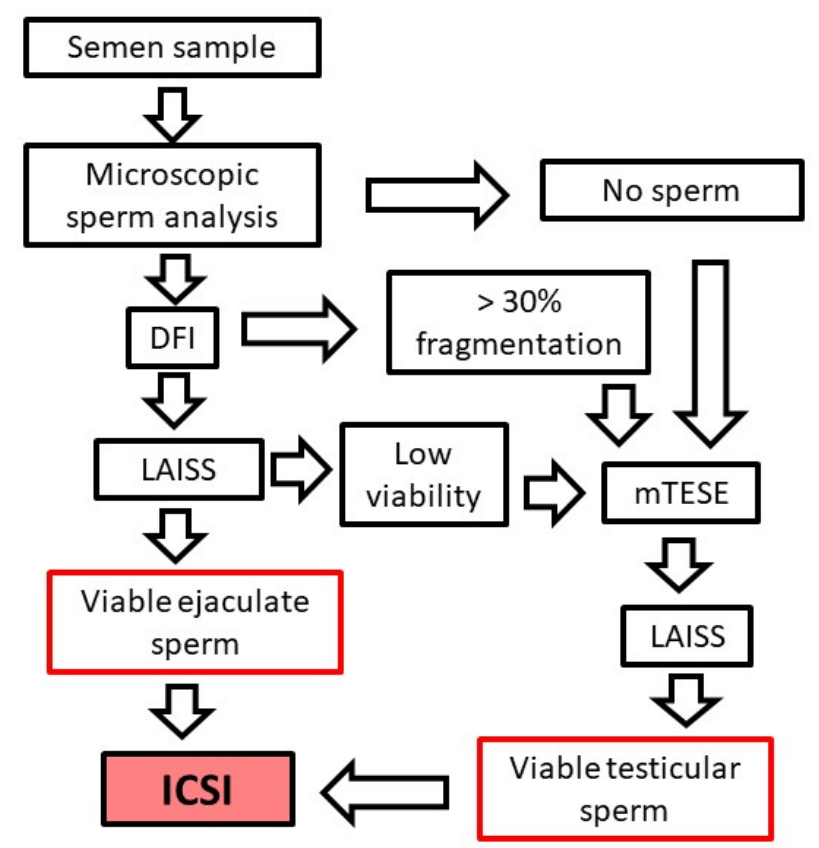

Figure 4. Schematic diagram of the diagnostic and treatment pipeline for male infertility in PCD. In PCD patients, a $55 \%$ fertilization rate was reported for ejaculated sperm and $65 \%$ for testicular sperm. Pregnancy rates vary between 35 and $45 \%$ for ejaculated and testicular sperm, respectively [90]. DFI = DNA fragmentation index, LAISS = laser-assisted immotile sperm selection, microdissection testicular sperm extraction (mTESE).

In the case that good quality viable sperm can be detected in the ejaculate, the selected viable sperm can be successfully used for ICSI. However, low sperm quality or count in ejaculated sperm decreases the fertilization success, and testicular sperm retrieval could be recommended (Figure 4). In all cases, patients should be informed about the possibility to pass on the PCD mutations to the next generation and the risks involved in any treatment techniques.

\section{Success of ART in PCD Patients}

The success rate of ICSI varies greatly in couples affected by PCD in the male partner. One important factor seems to be sperm viability, which can be affected by the transition time through the epididymis. As described before, motile cilia may play an important role in sperm transit through the efferent ductules to the epididymis. If this process is affected, sperm viability can decrease. Increased transport time may result in fragile sperm DNA, and hampered pronucleus formation in aged spermatozoa [58]. Furthermore, the type of ultrastructural defects may influence the rate of ICSI success as has been suggested by the association of central pair defects with lower clinical pregnancy rate [91,92]. Mutations affecting the centriolar function can prevent normal pro-nuclear development after fertilization, since the sperm centrosome is required for this process $[10,93]$. Thus, the ICSI success may depend on the mutated gene and its role in motile cilia and/or sperm flagellum.

Previous studies showed that patients with high sperm viability achieved reasonable fertilization rates, but patients with low sperm viability benefitted from testicular sperm retrieval [58]. Testicular sperm are generally very viable; sperm viability analysis showed that the viability difference between ejaculated and testicular sperm can be $<5 \%$ and $95 \%$, respectively $[83,94]$. These studies indicated that, in addition to severe oligospermia or azoospermia patients, who do not have enough sperm for ICSI, PCD patients with low sperm viability should consider testicular sperm extraction to improve treatment outcomes.

An early study evaluated the use of immotile ejaculated and testicular sperm in ICSI treatment [95]. This study showed no difference between HOS or laser selection for viable sperm, and the laser test was used for viable sperm selection for ICSI. The viability test improved fertilization success from 49 to $64 \%$ in ejaculated sperm and from 20 to 
$45 \%$ in testicular sperm. Live birth rates were 17 to $28 \%$ and 6 to $19 \%$ in ejaculated and testicular sperm, respectively. In PCD patients, fertilization and pregnancy rates ranging from 55 to $65 \%$ and from 35 to $45 \%$ in ejaculated and testicular sperm, respectively, were reported [90]. The overall live birth rate was estimated at 39\%. Slightly better results with ejaculated sperm were reported more recently: a fertilization rate of $69 \%$ and a clinical pregnancy rate of $67 \%$ [66]. Similar estimates were reported for MMAF patients: 63-68\%, $54-57 \%$, and $43 \%$ for fertilization, pregnancy, and live birth rates, respectively [66,96]. Successful clinical pregnancies by various methods have been reported for couples with male partner PCD [57,61,62,83-86,97-101] and for some known PCD genes [50,66,102-104], as summarized in Table 3.

Table 3. Reported ICSI treatments and outcomes in PCD patients.

\begin{tabular}{|c|c|c|c|c|c|c|}
\hline Gene & ICSI Result & Sperm Origin & $\begin{array}{l}\text { Reported Sperm } \\
\text { Phenotype }\end{array}$ & Viability \% & Sperm Count & Reference \\
\hline- & live birth & ejaculated sperm & immotile & 90 & normal & [97] \\
\hline- & live birth & $\begin{array}{l}\text { ejaculated sperm, } \\
\text { swim-up }\end{array}$ & $25 \%$ motility & nd & normal & [98] \\
\hline- & live birth & testicular sperm & azoospermia & nd & 0 & [83] \\
\hline- & live birth & testicular sperm & immotile & $<5 \%$ & low (4.8) & [83] \\
\hline- & live birth & testicular sperm & $\begin{array}{l}\text { immotile, severe } \\
\text { oligospermia }\end{array}$ & nd & extremely low & {$[57]$} \\
\hline - & pregnancy & testicular sperm & immotile & $>65$ & normal & [57] \\
\hline- & live birth & testicular sperm & immotile, malformed & nd & normal & [94] \\
\hline- & live birth & $\begin{array}{l}\text { viable ejaculated } \\
\text { sperm }\end{array}$ & $\begin{array}{l}\text { immotile, dynein arm } \\
\text { defect }\end{array}$ & 40 & normal & {$[61]$} \\
\hline- & live birth & $\begin{array}{l}\text { ejaculated sperm, } \\
\text { swim-up }\end{array}$ & $\begin{array}{l}0.3 \% \text { motile, lack of } \\
\text { dynein arms }\end{array}$ & 30 & normal & [99] \\
\hline- & no pregnancy & $\begin{array}{l}\text { viable ejaculated } \\
\text { and testicular }\end{array}$ & $\begin{array}{c}0.3 \% \text { motile, } 76.4 \% \text { DNA } \\
\text { fragmentation }\end{array}$ & 30 & low (1.2) & [74] \\
\hline- & live birth & $\begin{array}{l}\text { viable ejaculated } \\
\text { sperm }\end{array}$ & $\begin{array}{c}\text { immotile, dynein arm } \\
\text { defect }\end{array}$ & 54 & low $(0.9)$ & [85] \\
\hline- & live birth & testicular sperm & azoospermia & nd & 0 & [84] \\
\hline- & live birth & $\begin{array}{l}\text { viable ejaculated } \\
\text { sperm }\end{array}$ & immotile & nd & normal & [62] \\
\hline- & live birth & testicular sperm & immotile, malformed & 20 & low (10.1) & {$[100]$} \\
\hline- & live birth & $\begin{array}{l}\text { viable ejaculated } \\
\text { sperm, }\end{array}$ & $\begin{array}{l}\text { immotile, abnormal } \\
\text { morphology }\end{array}$ & 32 & low (1.8) & [86] \\
\hline- & live birth & $\begin{array}{l}\text { viable ejaculated } \\
\text { sperm }\end{array}$ & immotile & $60-74$ & normal & [101] \\
\hline- & no pregnancy & $\begin{array}{l}\text { viable ejaculated } \\
\text { sperm }\end{array}$ & immotile & $35-65$ & normal & [101] \\
\hline ZMYND10 & healthy baby & $\begin{array}{l}\text { viable ejaculated } \\
\text { sperm }\end{array}$ & $\begin{array}{l}\text { immotile, oligoas- } \\
\text { thenoteratozoospermia, } \\
\text { lack of dynein arms }\end{array}$ & 54 & low (2-9) & [69] \\
\hline CFAP74 & healthy baby & ejaculated sperm & $\begin{array}{l}\text { low motility }(2 \%) \\
\text { malformed }\end{array}$ & nd & normal & [103] \\
\hline DNAAF6 & healthy baby & $\begin{array}{l}\text { viable ejaculated } \\
\text { sperm }\end{array}$ & immotile & nd & low (5.2-11.2) & [104] \\
\hline DNAAF7 & healthy baby & $\begin{array}{l}\text { viable ejaculated } \\
\text { sperm }\end{array}$ & low motility $(8.6 \%)$ & nd & low (3.5-8.7) & [104] \\
\hline SPAG6 & healthy baby & $\begin{array}{l}\text { viable ejaculated } \\
\text { sperm }\end{array}$ & immotile, malformed & nd & normal & [66] \\
\hline RSPH3 & healthy baby & $\begin{array}{l}\text { viable ejaculated } \\
\text { sperm }\end{array}$ & immotile, malformed & nd & normal & [66] \\
\hline DNAH9 & $\begin{array}{l}\text { clinical } \\
\text { pregnancy }\end{array}$ & $\begin{array}{l}\text { motile ejaculated } \\
\text { sperm }\end{array}$ & $\begin{array}{l}\text { very low motility } \\
(0.3-0.8 \% \text { motile })\end{array}$ & $75-82$ & normal & [50] \\
\hline LRRC6 & $\begin{array}{l}\text { clinical } \\
\text { pregnancy }\end{array}$ & testicular sperm & $\begin{array}{l}\text { immotile, axoneme } \\
\text { defects }\end{array}$ & 75 & normal & [102] \\
\hline
\end{tabular}


Isolated studies with low numbers of patients have suggested improved methods, such as ionophore application immediately after ICSI, in addition to viability and DNA fragmentation tests [86]. Although recent developments in ART have dramatically improved the prognosis of ICSI in male PCD patients, additional research is required to understand the beneficial treatment options and improve the pipeline for PCD patient fertility treatment.

\section{Future Perspectives}

PCD is a complex disease caused by mutations in a large number of genes. The genetic background is not known in all cases, but ongoing research is characterizing novel genes in PCD patients. As the effects of causative PCD mutations on male fertility have not been systematically investigated, the first objective in future studies should be the comprehensive analysis of the roles of PCD genes in spermatogenesis and sperm maturation and transport. PCD mutations can influence the sperm tail formation by altering the axoneme structure and function, as was shown for genes coding for dynein arm preassembly factors and various structural proteins. These mutations often result in immotile and even malformed sperm tails, which complicates the selection of viable sperm for ICSI. A simple and reliable test to select sperm for ICSI is yet to come, and development of a standard pipeline for fertility treatment of PCD patients should be a high priority.

In addition to sperm tail formation, PCD genes may affect male fertility through efferent duct motile cilia. The importance of motile ED cilia was recently recognized, but the role of this cilia type is not understood in PCD patients. Interestingly, fertility and infertility was reported for genes not expressed during spermatogenesis in PCD patients. Furthermore, azoospermia was detected in few PCD patients, indicating a problem in sperm transport. It can be speculated that the variable sperm count in PCD patients is due to the malfunction of male-specific motile cilia. The role of ED cilia, and causes of variable fertility status, need to be studied in detail and may enable the development of novel treatment options for patients. Since defects in cilia motility may influence sperm transport and maturation, leading to quality issues, these processes should be understood to improve male factor fertility.

Author Contributions: Conceptualization, C.N.J. and A.S.; analysis, A.S.; writing-original draft preparation, C.N.J. and A.S.; writing-review and editing, C.N.J. and A.S.; visualization, A.S. All authors have read and agreed to the published version of the manuscript.

Funding: C.N.J. was funded by an NIHR Post-Doctoral Fellowship (PDF-2017-10-098) and the Imperial NIHR BRC.

Institutional Review Board Statement: Not applicable.

Informed Consent Statement: Not applicable.

Conflicts of Interest: The authors declare no conflict of interest.

\section{References}

1. Olbrich, H.; Schmidts, M.; Werner, C.; Onoufriadis, A.; Loges, N.T.; Raidt, J.; Banki, N.F.; Shoemark, A.; Burgoyne, T.; Al Turki, S.; et al. Recessive HYDIN mutations cause primary ciliary dyskinesia without randomization of left-right body asymmetry. Am. J. Hum. Genet. 2012, 91, 672-684. [CrossRef]

2. Heuser, T.; Dymek, E.E.; Lin, J.; Smith, E.F.; Nicastro, D. The CSC connects three major axonemal complexes involved in dynein regulation. Mol. Biol. Cell 2012, 23, 3143-3155. [CrossRef] [PubMed]

3. Lee, L.; Ostrowski, L.E. Motile cilia genetics and cell biology: Big results from little mice. Cell. Mol. Life Sci. $2021,78,769-797$. [CrossRef]

4. Fabczak, H.; Osinka, A. Role of the Novel Hsp90 Co-Chaperones in Dynein Arms' Preassembly. Int. J. Mol. Sci. 2019, $20,6174$. [CrossRef] [PubMed]

5. Osinka, A.; Poprzeczko, M.; Zielinska, M.M.; Fabczak, H.; Joachimiak, E.; Wloga, D. Ciliary proteins: Filling the gaps. Recent advances in deciphering the protein composition of motile ciliary complexes. Cells 2019, 8, 730. [CrossRef]

6. Lehti, M.S.; Sironen, A. Formation and function of sperm tail structures in association with sperm motility defects. Biol. Reprod. 2017, 97, 522-536. [CrossRef] [PubMed] 
7. Martinez, G.; Kherraf, Z.E.; Zouari, R.; Fourati Ben Mustapha, S.; Saut, A.; Pernet-Gallay, K.; Bertrand, A.; Bidart, M.; Hograindleur, J.P.; Amiri-Yekta, A.; et al. Whole-Exome sequencing identifies mutations in FSIP2 as a recurrent cause of multiple morphological abnormalities of the sperm flagella. Hum. Reprod. 2018, 33, 1973-1984. [CrossRef]

8. Elkina, Y.L.; Kuravsky, M.L.; Bragina, E.E.; Kurilo, L.F.; Khayat, S.S.; Sukhomlinova, M.Y.; Schmalhausen, E.V. Detection of a mutation in the intron of sperm-specific glyceraldehyde-3-phosphate dehydrogenase gene in patients with fibrous sheath dysplasia of the sperm flagellum. Andrologia 2017, 49, e12606. [CrossRef]

9. Liu, M.; Sun, Y.; Li, Y.; Sun, J.; Yang, Y.; Shen, Y. Novel mutations in FSIP2 lead to multiple morphological abnormalities of the sperm flagella and poor ICSI prognosis. Gene 2021, 781, 145536. [CrossRef]

10. Fishman, E.L.; Jo, K.; Nguyen, Q.P.H.; Kong, D.; Royfman, R.; Cekic, A.R.; Khanal, S.; Miller, A.L.; Simerly, C.; Schatten, G.; et al. A novel atypical sperm centriole is functional during human fertilization. Nat. Commun. 2018, 9, 2210. [CrossRef]

11. Wu, B.; Gao, H.; Liu, C.; Li, W. The coupling apparatus of the sperm head and tail. Biol. Reprod. 2020, 102, 988-998. [CrossRef] [PubMed]

12. Zur Lage, P.; Newton, F.G.; Jarman, A.P. Survey of the ciliary motility machinery of drosophila sperm and ciliated mechanosensory neurons reveals unexpected cell-type specific variations: A model for motile ciliopathies. Front. Genet. 2019, 10, 24. [CrossRef]

13. Whitfield, M.; Thomas, L.; Bequignon, E.; Schmitt, A.; Stouvenel, L.; Montantin, G.; Tissier, S.; Duquesnoy, P.; Copin, B.; Chantot, S.; et al. Mutations in DNAH17, encoding a sperm-specific axonemal outer dynein arm heavy chain, cause isolated male infertility due to asthenozoospermia. Am. J. Hum. Genet. 2019, 105, 98-112. [CrossRef] [PubMed]

14. Ishimoto, K.; Bloomfield-Gadêlha, H.; Gaffney, E.; Smith, D.; Kirkman-Brown, J.C. Coarse-Graining the Fluid Flow around a Human Sperm. Phys. Rev. Lett. 2017, 118, 124501. [CrossRef] [PubMed]

15. Smith, D.; Gaffney, E.; Blake, J. Modelling mucociliary clearance. Respir. Physiol. Neurobiol. 2008, 163, 178-188. [CrossRef] [PubMed]

16. Legendre, M.; Zaragosi, L.E.; Mitchison, H.M. Motile cilia and airway disease. Semin. Cell Dev. Biol. 2021, 110, 19-33. [CrossRef] [PubMed]

17. Backman, K.; Mears, W.E.; Waheeb, A.; Beaulieu Bergeron, M.; McClintock, J.; de Nanassy, J.; Reisman, J.; Osmond, M.; Hartley, T.; Mears, A.J.; et al. A splice site and copy number variant responsible for TTC25-related primary ciliary dyskinesia. Eur. J. Med. Genet. 2021, 64, 104193. [CrossRef] [PubMed]

18. Fagerberg, L.; Hallström, B.M.; Oksvold, P.; Kampf, C.; Djureinovic, D.; Odeberg, J.; Habuka, M.; Tahmasebpoor, S.; Danielsson, A.; Edlund, K.; et al. Analysis of the Human tissue-specific expression by genome-wide integration of transcriptomics and antibody-based proteomics. Mol. Cell. Proteom. 2014, 13, 397-406. [CrossRef]

19. Shoemark, A.; Harman, K. Primary Ciliary Dyskinesia. Semin. Respir. Crit. Care Med. 2021, 42, 537-548. [CrossRef] [PubMed]

20. Sironen, A.; Shoemark, A.; Patel, M.; Loebinger, M.R.; Mitchison, H.M. Sperm defects in primary ciliary dyskinesia and related causes of male infertility. Cell. Mol. Life Sci. 2019, 77, 2029-2048. [CrossRef]

21. Tu, C.; Nie, H.; Meng, L.; Wang, W.; Li, H.; Yuan, S.; Cheng, D.; He, W.; Liu, G.; Du, J.; et al. Novel mutations in SPEF2 causing different defects between flagella and cilia bridge: The phenotypic link between MMAF and PCD. Qual. Life Res. 2020, 139, 257-271. [CrossRef]

22. Liu, C.; Lv, M.; He, X.; Zhu, Y.; Amiri-Yekta, A.; Li, W.; Wu, H.; Kherraf, Z.E.; Liu, W.; Zhang, J.; et al. Homozygous mutations in SPEF2 induce multiple morphological abnormalities of the sperm flagella and male infertility. J. Med. Genet. 2019, 57, 31-37. [CrossRef] [PubMed]

23. Liu, W.; Sha, Y.; Li, Y.; Mei, L.; Lin, S.; Huang, X.; Lu, J.; Ding, L.; Kong, S.; Lu, Z. Loss-of-function mutations in SPEF2 cause multiple morphological abnormalities of the sperm flagella (MMAF). J. Med. Genet. 2019, 56, 678-684. [CrossRef] [PubMed]

24. Coutton, C.; Martinez, G.; Kherraf, Z.E.; Amiri-Yekta, A.; Boguenet, M.; Saut, A.; He, X.; Zhang, F.; Cristou-Kent, M.; Escoffier, J.; et al. Bi-allelic Mutations in ARMC2 lead to severe astheno-teratozoospermia due to sperm flagellum malformations in humans and mice. Am. J. Hum. Genet. 2019, 104, 331-340. [CrossRef] [PubMed]

25. Dong, F.N.; Amiri-Yekta, A.; Martinez, G.; Saut, A.; Tek, J.; Stouvenel, L.; Lores, P.; Karaouzene, T.; Thierry-Mieg, N.; Satre, V.; et al. Absence of CFAP69 causes male infertility due to multiple morphological abnormalities of the flagella in human and mouse. Am. J. Hum. Genet. 2018, 102, 636-648. [CrossRef]

26. He, X.; Li, W.; Wu, H.; Lv, M.; Liu, W.; Liu, C.; Zhu, F.; Li, C.; Fang, Y.; Yang, C.; et al. Novel homozygous CFAP69 mutations in humans and mice cause severe asthenoteratospermia with multiple morphological abnormalities of the sperm flagella. J. Med. Genet. 2018, 56, 96-103. [CrossRef]

27. Lorès, P.; Coutton, C.; El Khouri, E.; Stouvenel, L.; Givelet, M.; Thomas, L.; Rode, B.; Schmitt, A.; Louis, B.; Sakheli, Z.; et al. Homozygous missense mutation L673P in adenylate kinase 7 (AK7) leads to primary male infertility and multiple morphological anomalies of the flagella but not to primary ciliary dyskinesia. Hum. Mol. Genet. 2018, 27, 1196-1211. [CrossRef]

28. Mata, M.; Lluch-Estellés, J.; Armengot, M.; Sarrión, I.; Carda, C.; Cortijo, J. New Adenylate Kinase 7 (AK7) Mutation in Primary Ciliary Dyskinesia. Am. J. Rhinol. Allergy 2012, 26, 260-264. [CrossRef]

29. Milara, J.; Armengot, M.; Mata, M.; Morcillo, E.; Cortijo, J. Role of Adenylate kinase Type 7 expression on cilia motility: Possible link in primary ciliary dyskinesia. Am. J. Rhinol. Allergy 2010, 24, 181-185. [CrossRef]

30. Jeanson, L.; Copin, B.; Papon, J.F.; Moal, F.D.-L.; Duquesnoy, P.; Montantin, G.; Cadranel, J.; Corvol, H.; Coste, A.; Désir, J.; et al. RSPH3 Mutations cause primary ciliary dyskinesia with central-complex defects and a near absence of radial spokes. Am. J. Hum. Genet. 2015, 97, 153-162. [CrossRef] [PubMed] 
31. Vanaken, G.J.; Bassinet, L.; Boon, M.; Mani, R.; Honore, I.; Papon, J.F.; Cuppens, H.; Jaspers, M.; Lorent, N.; Coste, A.; et al. Infertility in an adult cohort with primary ciliary dyskinesia: Pheno-type-gene association. Eur. Respir. J. 2017, 50, 1700314. [CrossRef] [PubMed]

32. Castleman, V.H.; Romio, L.; Chodhari, R.; Hirst, R.A.; de Castro, S.C.; Parker, K.A.; Ybot-Gonzalez, P.; Emes, R.D.; Wilson, S.; Wallis, C.; et al. Mutations in Radial Spoke Head Protein Genes RSPH9 and RSPH4A Cause Primary Ciliary Dyskinesia with Central-Microtubular-Pair Abnormalities. Am. J. Hum. Genet. 2009, 84, 197-209. [CrossRef] [PubMed]

33. Abbasi, F.; Miyata, H.; Shimada, K.; Morohoshi, A.; Nozawa, K.; Matsumura, T.; Xu, Z.; Pratiwi Pikawa, M. RSPH6A is required for sperm flagellum formation and male fertility in mice. J. Cell Sci. 2018, 131, jcs221648. [CrossRef] [PubMed]

34. Aprea, I.; Raidt, J.; Höben, I.M.; Loges, N.T.; Nöthe-Menchen, T.; Pennekamp, P.; Olbrich, H.; Kaiser, T.; Biebach, L.; Tüttelmann, F.; et al. Defects in the cytoplasmic assembly of axonemal dynein arms cause morphological abnormalities and dysmotility in sperm cells leading to male infertility. PLoS Genet. 2021, 17, e1009306. [CrossRef]

35. Thomas, L.; Bouhouche, K.; Whitfield, M.; Thouvenin, G.; Coste, A.; Louis, B.; Szymanski, C.; Bequignon, E.; Papon, J.F.; Castelli, M.; et al. TTC12 Loss-of-Function mutations cause primary ciliary dyskinesia and unveil distinct dynein assembly mechanisms in motile cilia versus flagella. Am. J. Hum. Genet. 2020, 106, 153-169. [CrossRef]

36. Fliegauf, M.; Olbrich, H.; Horvath, J.; Wildhaber, J.H.; Zariwala, M.A.; Kennedy, M.; Knowles Mromran, H. Mislocalization of DNAH5 and DNAH9 in respiratory cells from patients with primary ciliary dyskinesia. Am. J. Respir. Crit. Care Med. 2005, 171, 1343-1349. [CrossRef] [PubMed]

37. Schwabe, G.C.; Hoffmann, K.; Loges, N.T.; Birker, D.; Rossier, C.; de Santi, M.M.; Olbrich, H.; Fliegauf, M.; Failly, M.; Liebers, U.; et al. Primary ciliary dyskinesia associated with normal axoneme ultrastructure is caused by DNAH11 mutations. Hum. Mutat. 2008, 29, 289-298. [CrossRef]

38. Wang, X.; Jin, H.; Han, F.; Cui, Y.; Chen, J.; Yang, C.; Zhu, P.; Jiao, G.; Wang, W.; Hao, C.; et al. Homozygous DNAH1 frameshift mutation causes multiple morphological anomalies of the sperm flagella in Chinese. Clin. Genet. 2016, 91, 313-321. [CrossRef]

39. Amiri-Yekta, A.; Coutton, C.; Kherraf, Z.E.; Karaouzene, T.; Le Tanno, P.; Sanati, M.H.; Sabbaghian, M.; Almadani, N.; Sadighi Gilani, M.A.; Hosseini, S.H.; et al. Whole-exome sequencing of familial cases of multiple morphological abnormalities of the sperm flagella (MMAF) reveals new DNAH1 mutations. Hum. Reprod. 2016, 31, 2872-2880. [CrossRef] [PubMed]

40. Imtiaz, F.; Allam, R.; Ramzan, K.; Al-Sayed, M. Variation in DNAH1 may contribute to primary ciliary dyskinesia. BMC Med. Genet. 2015, 16, 14. [CrossRef]

41. Ben Khelifa, M.; Coutton, C.; Zouari, R.; Karaouzène, T.; Rendu, J.; Bidart, M.; Yassine, S.; Pierre, V.; Delaroche, J.; Hennebicq, S.; et al. Mutations in DNAH1, which encodes an inner arm heavy chain dynein, lead to male infertility from multiple morphological abnormalities of the sperm flagella. Am. J. Hum. Genet. 2014, 94, 95-104. [CrossRef] [PubMed]

42. Li, Y.; Sha, Y.; Wang, X.; Ding, L.; Liu, W.; Ji, Z.; Mei, L.; Huang, X.; Lin, S.; Kong, S.; et al. DNAH2 is a novel candidate gene associated with multiple morphological abnormalities of the sperm flagella. Clin. Genet. 2019, 95, 590-600. [CrossRef] [PubMed]

43. Liu, C.; Miyata, H.; Gao, Y.; Sha, Y.; Tang, S.; Xu, Z.; Whitfield, M.; Patrat, C.; Wu, H.; Dulioust, E.; et al. Bi-Allelic DNAH8 variants lead to multiple morphological abnormalities of the sperm flagella and primary male infertility. Am. J. Hum. Genet. 2020, 107, 330-341. [CrossRef]

44. Yang, Y.; Jiang, C.; Zhang, X.; Liu, X.; Li, J.; Qiao, X.; Liu, H.; Shen, Y. Loss-of-function mutation in DNAH8 induces asthenoteratospermia associated with multiple morphological abnormalities of the sperm flagella. Clin. Genet. 2020, 98, 396-401. [CrossRef]

45. Zhou, Z.; Mao, X.; Chen, B.; Mu, J.; Wang, W.; Li, B.; Yan, Z.; Dong, J.; Li, Q.; Kuang, Y.; et al. A novel splicing variant in DNAH8 causes asthenozoospermia. J. Assist. Reprod. Genet. 2021, 1545-1550. [CrossRef] [PubMed]

46. Weng, M.; Sha, Y.; Zeng, Y.U.; Huang, N.; Liu, W.; Zhang, X.; Zhou, H. Mutations in DNAH8 contribute to multiple morphological abnormalities of sperm flagella and male infertility. Acta Biochim. Biophys. Sin. 2021, 53, 472-480. [CrossRef] [PubMed]

47. Zhang, B.; Ma, H.; Khan, T.; Ma, A.; Li, T.; Zhang, H.; Gao, J.; Zhou, J.; Li, Y.; Yu, C.; et al. A DNAH17 missense variant causes flagella destabilization and asthenozoospermia. J. Exp. Med. 2020, 217, e20182365. [CrossRef]

48. Sha, Y.; Wei, X.; Ding, L.; Mei, L.; Huang, X.; Lin, S.; Su, Z.; Kong, L.; Zhang, Y.; Ji, Z. DNAH17 is associated with asthenozoospermia and multiple morphological abnormalities of sperm flagella. Ann. Hum. Genet. 2019, 84, 271-279. [CrossRef] [PubMed]

49. Zhang, B.; Khan, I.; Liu, C.; Ma, A.; Khan, A.; Zhang, Y.; Zhang, H.; Kakakhel, M.B.S.; Zhou, J.; Zhang, W.; et al. Novel loss-of-function variants in DNAH17 cause multiple morphological abnormalities of the sperm flagella in humans and mice. Clin. Genet. 2020, 99, 176-186. [CrossRef]

50. Tang, D.; Sha, Y.; Gao, Y.; Zhang, J.; Cheng, H.; Zhang, J.; Ni, X.; Wang, C.; Xu, C.; Geng, H.; et al. Novel variants in DNAH9 lead to nonsyndromic severe asthenozoospermia. Reprod. Biol. Endocrinol. 2021, 19, 27. [CrossRef]

51. Fassad, M.R.; Shoemark, A.; Legendre, M.; Hirst, R.A.; Koll, F.; le Borgne, P.; Louis, B.; Daudvohra, F.; Patel, M.P.; Thomas, L.; et al. Mutations in outer dynein arm heavy chain DNAH9 cause motile cilia defects and situs inversus. Am. J. Hum. Genet. 2018, 103, 984-994. [CrossRef]

52. Loges, N.T.; Antony, D.; Maver, A.; Deardorff, M.A.; Gulec, E.Y.; Gezdirici, A.; Nothe-Menchen, T.; Hoben, I.M.; Jelten, L.; Frank, D.; et al. Recessive DNAH9 Loss-of-Function mutations cause laterality defects and subtle respiratory ciliary-beating defects. Am. J. Hum. Genet. 2018, 103, 995-1008. [CrossRef] 
53. Terré, B.; Lewis, M.; Gil-Gómez, G.; Han, Z.; Hao, L.; Aguilera, M.; Prats, N.; Roy, S.; Zhao, H.; Stracker, T.H. Defects in efferent duct multiciliogenesis underlie male infertility in GEMC1, MCIDAS or CCNO deficient mice. Development 2019, 146, 162628. [CrossRef]

54. Yuan, S.; Liu, Y.; Peng, H.; Tang, C.; Hennig, G.W.; Wang, Z.; Wang, L.; Yu, T.; Klukovich, R.; Zhang, Y.; et al. Motile cilia of the male reproductive system require miR-34/miR-449 for development and function to generate luminal turbulence. Proc. Natl. Acad. Sci. USA 2019, 116, 3584-3593. [CrossRef]

55. Zhou, J.; Chen, L.; Li, J.; Li, H.; Hong, Z.; Xie, M.; Chen, S.; Yao, B. The Semen pH Affects Sperm Motility and Capacitation. PLoS ONE 2015, 10, e0132974. [CrossRef]

56. Shibahara, H.; Hamada, Y.; Hasegawa, A.; Wakimoto, E.; Toji, H.; Shigeta, M.; Koyama, K. Relationship between the sperm motility index assessed by the sperm quality analyzer and the outcome of intracytoplasmic sperm injection. J. Assist. Reprod. Genet. 1999, 16, 540-545. [CrossRef]

57. Westlander, G.; Barry, M.; Petrucco, O.; Norman, R. Different fertilization rates between immotile testicular spermatozoa and immotile ejaculated spermatozoa for ICSI in men with Kartagener's syndrome: Case reports. Hum. Reprod. 2003, 18, 1286-1288 [CrossRef]

58. Niu, Z.-H.; Huang, X.-F.; Jia, X.-F.; Zheng, J.; Yuan, Y.; Shi, T.-Y.; Diao, H.; Yu, H.-G.; Sun, F.; Zhang, H.-Q.; et al. A sperm viability test using SYBR-14/propidium iodide flow cytometry as a tool for rapid screening of primary ciliary dyskinesia patients and for choosing sperm sources for intracytoplasmic sperm injection. Fertil. Steril. 2011, 95, 389-392. [CrossRef]

59. Sallam, H.N.; Farrag, A.; Agameya, A.F.; El-Garem, Y.; Ezzeldin, F. The use of the modified hypo-osmotic swelling test for the selection of immotile testicular spermatozoa in patients treated with ICSI: A randomized controlled study. Hum. Reprod. 2005, 20, 3435-3440. [CrossRef]

60. Nordhoff, V. How to select immotile but viable spermatozoa on the day of intracytoplasmic sperm injection? An embryologist's view. Andrology 2014, 3, 156-162. [CrossRef]

61. Kordus, R.J.; Price, R.L.; Davis, J.M.; Whitman-Elia, G.F. Successful twin birth following blastocyst culture of embryos derived from the immotile ejaculated spermatozoa from a patient with primary ciliary dyskinesia: A case report. J. Assist. Reprod. Genet. 2008, 25, 437-443. [CrossRef]

62. Geber, S.; Lemgruber, M.; Taitson, P.F.; Valle, M.; Sampaio, M. Birth of healthy twins after intracytoplasmic sperm injection using ejaculated immotile spermatozoa from a patient with Kartagener's syndrome. Andrologia 2011, 44, 842-844. [CrossRef]

63. Mangoli, V.; Mangoli, R.; Dandekar, S.; Suri, K.; Desai, S. Selection of viable spermatozoa from testicular biopsies: A comparative study between pentoxifylline and hypoosmotic swelling test. Fertil. Steril. 2011, 95, 631-634. [CrossRef]

64. Yildirim, G.; Ficicioglu, C.; Akçin, O.; Attar, R.; Tecellioglu, N.; Yencilek, F. Can pentoxifylline improve the sperm motion and ICSI success in the primary ciliary dyskinesia? Arch. Gynecol. Obstet. 2008, 279, 213-215. [CrossRef]

65. De Oliveira, N.M.; Sánchez, R.V.; Fiesta, S.R.; Salgado, T.L.; Rodríguez, R.; Bethencourt, J.C.; Zamora, R.B. Pregnancy with frozen-thawed and fresh testicular biopsy after motile and immotile sperm microinjection, using the mechanical touch technique to assess viability. Hum. Reprod. 2004, 19, 262-265. [CrossRef]

66. Wu, H.; Wang, J.; Cheng, H.; Gao, Y.; Liu, W.; Zhang, Z.; Jiang, H.; Li, W.; Zhu, F.; Lv, M.; et al. Patients with severe asthenoteratospermia carrying SPAG6 or RSPH3 mutations have a positive pregnancy outcome following intracytoplasmic sperm injection. J. Assist. Reprod. Genet. 2020, 37, 829-840. [CrossRef]

67. Chen, H.; Feng, G.; Zhang, B.; Zhou, H.; Shu, J.; Gan, X. A successful pregnancy using completely immotile but viable frozenthawed spermatozoa selected by laser. Clin. Exp. Reprod. Med. 2017, 44, 52-55. [CrossRef]

68. Gerber, P.A.; Kruse, R.; Hirchenhain, J.; Krussel, J.S.; Neumann, N.J. Pregnancy after laser-assisted selection of viable sper-matozoa before intracytoplasmatic sperm injection in a couple with male primary cilia dyskinesia. Fertil. Steril. 2008, 89, 1826.e9-1826.e12 [CrossRef]

69. Ozkavukcu, S.; Celik-Ozenci, C.; Konuk, E.; Atabekoğlu, C.S. Live birth after Laser Assisted Viability Assessment (LAVA) to detect pentoxifylline resistant ejaculated immotile spermatozoa during ICSI in a couple with male Kartagener's syndrome. Reprod. Biol. Endocrinol. 2018, 16, 10. [CrossRef]

70. Samplaski, M.K.; Dimitromanolakis, A.; Lo, K.C.; Grober, E.D.; Mullen, B.; Garbens, A.; Jarvi, K.A. The relationship between sperm viability and DNA fragmentation rates. Reprod. Biol. Endocrinol. 2015, 13, 42. [CrossRef]

71. Aydos, O.S.; Yukselten, Y.; Kaplan, F.; Sunguroglu, A.; Aydos, K. Analysis of the correlation between sperm DNA integrity and conventional semen parameters in infertile men. Turk. J. Urol. 2015, 41, 191-197. [CrossRef]

72. Belloc, S.; Benkhalifa, M.; Cohen-Bacrie, M.; Dalleac, A.; Amar, E.; Zini, A. Sperm deoxyribonucleic acid damage in normozoospermic men is related to age and sperm progressive motility. Fertil. Steril. 2014, 101, 1588-1593. [CrossRef]

73. Derijck, A.A.; van der Heijden, G.W.; Ramos, L.; Giele, M.; Kremer, J.; Ade Boer, P. Motile human normozoospermic and oligozoospermic semen samples show a difference in double-strand DNA break incidence. Hum. Reprod. 2007, 22, $2368-2376$. [CrossRef]

74. Nuñez, R.; López-Fernández, C.; Arroyo, F.; Caballero, P.; Gosalvez, J. Characterization of sperm DNA damage in Kartagener's syndrome with recurrent fertilization failure: Case revisited. Sex. Reprod. Healthc. 2010, 1, 73-75. [CrossRef]

75. Da Costa, R.; Redmann, K.; Schlatt, S. Simultaneous detection of sperm membrane integrity and DNA fragmentation by flow cytometry: A novel and rapid tool for sperm analysis. Andrology 2021, 9, 1254-1263. [CrossRef] [PubMed] 
76. Campagne, D.M. Can Male Fertility Be Improved Prior to Assisted Reproduction through The Control of Uncommonly Considered Factors? Int. J. Fertil. Steril. 2013, 6, 214-223. [PubMed]

77. Loutradi, K.E.; Tarlatzis, B.C.; Goulis, D.G.; Zepiridis, L.; Pagou, T.; Chatziioannou, E.; Grimbizis, G.F.; Papadimas IBontis, I. The effects of sperm quality on embryo development after intracytoplasmic sperm injection. J. Assist. Reprod. Genet. 2006, $23,69-74$. [CrossRef] [PubMed]

78. Borges, E.; Setti, A.S.; Braga, D.P.A.F.; Figueira, R.C.S.; Iaconelli, A. Total motile sperm count has a superior predictive value over the WHO 2010 cut-off values for the outcomes of intracytoplasmic sperm injection cycles. Andrology 2016, 4, 880-886. [CrossRef]

79. Hotaling, J.M.; Smith, J.F.; Rosen, M.; Muller, C.H.; Walsh, T.J. The relationship between isolated teratozoospermia and clinical pregnancy after in vitro fertilization with or without intracytoplasmic sperm injection: A systematic review and meta-analysis. Fertil. Steril. 2011, 95, 1141-1145. [CrossRef] [PubMed]

80. De Vos, A.; van De Velde, H.; Joris, H.; Verheyen, G.; Devroey, P.; van Steirteghem, A. Influence of individual sperm mor-phology on fertilization, embryo morphology, and pregnancy outcome of intracytoplasmic sperm injection. Fertil. Steril. 2003, 79, 42-48. [CrossRef]

81. Magli, M.C.; Gianaroli, L.; Ferraretti, A.P.; Gordts, S.; Fredericks, V.; Crippa, A. Paternal contribution to aneuploidy in preimplantation embryos. Reprod. Biomed. Online 2009, 18, 536-542. [CrossRef]

82. Munro, N.C.; Currie, D.C.; Lindsay, K.S.; Ryder, T.A.; Rutman, A.; Dewar, A.; Greenstone, M.A.; Hendry, W.F.; Cole, P.J. Fertility in men with primary ciliary dyskinesia presenting with respiratory infection. Thorax 1994, 49, 684-687. [CrossRef] [PubMed]

83. Cayan, S.; Conaghan, J.; Schriock, E.D.; Ryan, I.P.; Black, L.D.; Turek, P.J. Birth after intracytoplasmic sperm injection with use of testicular sperm from men with Kartagener/immotile cilia syndrome. Fertil. Steril. 2001, 76, 612-614. [CrossRef]

84. Vicdan, K.; Akarsu, C.; Vicdan, A.; Sozen, E.; Buluc, B.; Biberoĝlu, K.; Ozogul, C. Birth of a healthy boy using fresh testicular sperm in a patient with Klinefelter syndrome combined with Kartagener syndrome. Fertil. Steril. 2011, 96, 577-579. [CrossRef]

85. Hattori, H.; Nakajo, Y.; Ito, C.; Toyama, Y.; Toshimori, K.; Kyono, K. Birth of a healthy infant after intracytoplasmic sperm injection using pentoxifylline-activated sperm from a patient with Kartagener's syndrome. Fertil. Steril. 2011, 95, 2431.e9-2431.e11. [CrossRef]

86. Ebner, T.; Maurer, M.; Oppelt, P.; Mayer, R.B.; Duba, H.C.; Costamoling, W.; Shebl, O. Healthy twin live-birth after ionophore treatment in a case of theophylline-resistant Kartagener syndrome. J. Assist. Reprod. Genet. 2015, 32, 873-877. [CrossRef]

87. Schlegel, P.N. Testicular sperm extraction: Microdissection improves sperm yield with minimal tissue excision. Hum. Reprod. 1999, 14, 131-135. [CrossRef]

88. Deruyver, Y.; Vanderschueren, D.; van Der Aa, F. Outcome of microdissection TESE compared with conventional TESE in non-obstructive azoospermia: A systematic review. Andrology 2013, 2, 20-24. [CrossRef]

89. Bernie, A.M.; Mata, D.A.; Ramasamy, R.; Schlegel, P.N. Comparison of microdissection testicular sperm extraction, conventional testicular sperm extraction, and testicular sperm aspiration for nonobstructive azoospermia: A systematic review and meta-analysis. Fertil. Steril. 2015, 104, 1099-1103.e3. [CrossRef] [PubMed]

90. Coutton, C.; Escoffier, J.; Martinez, G.; Arnoult, C.; Ray, P.F. Teratozoospermia: Spotlight on the main genetic actors in the human Hum. Reprod. Update 2015, 21, 455-485. [CrossRef]

91. Mitchell, V.; Rives, N.; Albert, M.; Peers, M.C.; Selva, J.; Clavier, B.; Escudier, E.; Escalier, D. Outcome of ICSI with ejaculated spermatozoa in a series of men with distinct ultrastructural flagellar abnormalities. Hum. Reprod. 2006, 21, 2065-2074. [CrossRef]

92. Fauque, P.; Albert, M.; Serres, C.; Viallon, V.; Davy, C.; Epelboin, S.; Chalas, C.; Jouannet, P.; Patrat, C. From ultrastructural flagellar sperm defects to the health of babies conceived by ICSI. Reprod. Biomed. Online 2009, 19, 326-336. [CrossRef]

93. Terada, Y.; Schatten, G.; Hasegawa, H.; Yaegashi, N. Essential roles of the sperm centrosome in human fertilization: Developing the therapy for fertilization failure due to sperm centrosomal dysfunction. Tohoku J. Exp. Med. 2010, 220, 247-258. [CrossRef] [PubMed]

94. Kaushal, M.; Baxi, A. Birth after intracytoplasmic sperm injection with use of testicular sperm from men with Kartagener or immotile cilia syndrome. Fertil. Steril. 2007, 88, 497.e9-497.e11. [CrossRef] [PubMed]

95. Aktan, T.M.; Montag, M.; Duman, S.; Gorkemli, H.; Rink, K.; Yurdakul, T. Use of a laser to detect viable but immotile sper-matozoa. Andrologia 2004, 36, 366-369. [CrossRef]

96. Garza, S.D.; Patrizio, P. Reproductive outcomes in patients with male infertility because of Klinefelter's syndrome, Kartagener's syndrome, round-head sperm, dysplasia fibrous sheath, and 'stump' tail sperm. Curr. Opin. Obstet. Gynecol. 2013, 25, 229-246. [CrossRef]

97. Vodistincn Zumbusch, A.; Fiedler, K.; Mayerhofer, A.; Jessberger, B.; Ring, J.; Vogt, H.J. Birth of healthy children after intracytoplasmic sperm injection in two couples with male Kartagener's syndrome. Fertil. Steril. 1998, 70, 643-646. [CrossRef]

98. Kay, V.; Irvine, D. Successful in-vitro fertilization pregnancy with spermatozoa from a patient with Kartagener's syndrome: Case Report. Hum. Reprod. 2000, 15, 135-138. [CrossRef]

99. Matsumoto, Y.; Goto, S.; Hashimoto, H.; Kokeguchi, S.; Shiotani, M.; Okada, H. A healthy birth after intracytoplasmic sperm injection using ejaculated spermatozoa from a patient with Kartagener's syndrome. Fertil. Steril. 2010, 93, 2074.e17-2074.e19. [CrossRef]

100. McLachlan, R.I.; Ishikawa, T.; Osianlis, T.; Robinson, P.; Merriner, D.J.; Healy, D.; de Kretser, D.; O’Bryan, M.K. Normal live birth after testicular sperm extraction and intracytoplasmic sperm injection in variant primary ciliary dyskinesia with completely immotile sperm and structurally abnormal sperm tails. Fertil. Steril. 2012, 97, 313-318. [CrossRef] 
101. Montjean, D.; Courageot, J.; Altié, A.; Amar-Hoffet, A.; Rossin, B.; Geoffroy-Siraudin, C.; Tourame, P.; Boyer, P. Normal live birth after vitrified/warmed oocytes intracytoplasmic sperm injection with immotile spermatozoa in a patient with Kartagener's syndrome. Andrologia 2014, 47, 839-845. [CrossRef]

102. Li, Y.; Jiang, C.; Zhang, X.; Liu, M.; Sun, Y.; Yang, Y.; Shen, Y. The effect of a novel LRRC6 mutation on the flagellar ultrastructure in a primary ciliary dyskinesia patient. J. Assist. Reprod. Genet. 2021, 38, 689-696. [CrossRef] [PubMed]

103. Sha, Y.; Wei, X.; Ding, L.; Ji, Z.; Mei, L.; Huang, X.; Su, Z.; Wang, W.; Zhang, X.; Lin, S. Biallelic mutations of CFAP74 may cause human primary ciliary dyskinesia and MMAF phenotype. J. Hum. Genet. 2020, 65, 961-969. [CrossRef] [PubMed]

104. Wang, Y.; Tu, C.; Nie, H.; Meng, L.; Li, D.; Wang, W.; Zhang, H.; Lu, G.; Lin, G.; Tan, Y.-Q.; et al. Novel DNAAF6 variants identified by whole-exome sequencing cause male infertility and primary ciliary dyskinesia. J. Assist. Reprod. Genet. 2020, 37, 811-820. [CrossRef] [PubMed] 